\title{
PARADIGMA PENDIDIKAN ISLAM DALAM \\ MEMBANGUN MASYARAKAT MADANI
}

\author{
Mohammad Riza Zainuddin \\ STAI Muhammadiyah Tulungagung \\ riza77.zainuddin@gmail.com
}

\begin{abstract}
Education is basically aimed at developing one's personality, so that he becomes intelligent human being and able to solve various problems of life he faces. Islamic education not only teaches or transforms science and skills and sensitivity of taste or religion. But it should provide equipment to students to be able to solve the problems that are visible now and the new look clear in the future. Able to solve problems that are seen as their own obligations either as professionals who are bound to the code of ethics of his profession or because of the inner commitment between himself and God as a humanitarian obligation that consciously and sincerely sees the effort as a useful step for the environment. In other words, Islamic education must be oriented to the future because the real protege of today is the next generation in the future. From here develop the thinking about civil society, a civilized society, put forward pluralism, tasamuh (tolerance) and rule of law without abandoning the devotion to Allah SWT. The development of civil society can not be separated from the support of education, both formal and non-formal education, carried out through holistic and universal divine rules without any dichotomy of thought and time constraints that limit the process of coaching itself. Thus, the civil society will be formed if there is a cadre in every Muslim person by following the Islamic education kaffah, so that he can shine (mendakwahi) others kejalan truth.
\end{abstract}

Keywords: Paradigma of Islamic Education, Civil Society

\section{Pendahuluan}

Setelah selama 32 tahun Bangsa Indonesia mengalami era kediktatoran dan sistem pemerintahan militeristik di bawah rezim Orde Baru, reformasi pun bergulir pada tanggal 20 Mei 1998. Selanjutnya muncul berbagai wacana dan arah pembangunan masyarakat Indonesia. Di antaranya, opini-opini publik tentang civil society (masyarakat sipil), yaitu dengan menolak Dwi Fungsi ABRI dan memberdayakan masyarakat 
sipil dalam tatanan pemerintahan. Dari sinilah berkembang pemikiran tentang masyarakat madani, yaitu suatu masyarakat yang berperadaban, mengedepankan pluralisme, tasamuh (toleransi) dan supremasi hukum tanpa meninggalkan ketaqwaan kepada Allah Swt.

Istilah masyarakat madani, menurut Fachry Ali (1998), pertama kali dilontarkan oleh DR. Anwar Ibrahim, yaitu sebagai sebutan dari masyarakat Madinah yang berada di zaman Rasulullah Saw. Tepatnya setelah adanya perjanjian Madinah pada tahun ke-7 H. Adapun salah satu butirnya adalah 'Orang-orang yahudi dan muslim harus saling tolongmenolong dalam menghadapi orang yang hendak menyerang Yatsrib" (Rahman, 1997:256).

Dalam Piagam Madinah ini, digambarkan nilai-nilai inklusifisme (terbuka) dan tasamuh (toleransi) bukan wujud pemaksaan kehendak dalam beragama (QS. Al-Baqarah : 56), walaupun di Madinah terdapat 3 golongan besar, yaitu (1) sahabat-sahabat mulia (Anshar dan Muhajirin), (2) orang-orang Musyrik yang tidak mau beriman, dan (3) orang-orang Yahudi. Dengan akhlaknya yang mulia, Rasulullah Saw. terus berupaya mengembangkan dakwah Islamiyah pada seluruh kabilah di Madinah. Dampaknya, beliau ditunjuk sebagai pemimpin di Madinah oleh kaum Muslimin dan Musyrikin. Hal ini karena akhlaknya yang mulia dan sifatnya yang adil. Allah Swt. berfirman,

"Sesungguhnya pada diri Rasulullah (Muhammad) terdapat suri tauladan yang baik bagimu. Yaitu, bagi orang-orang yang mengharapakan Allah dan hari kemudian, serta ia banyak mengingat Allah" (QS. Al-Ahzab: 21).

Keberhasilan Rasulullah dalam membangun masyarakat di Madinah salah satunya disebabkan oleh pendidikan Rasulullah pada para sahabat, yaitu melalui pembinaan spiritual di Masjid Nabawi, Madinah. Kemudian Beliau melakukan konsolidasi internal dengan mempersaudarakan sahabat Muhajirin dan Anshar, bahkan termaktub dalam 16 butir perjanjian Islamiyah. Allah Swt. menceritakan kejadian ini dalam Al-Qur'an, surat AlHujurat, ayat 10, "Orang-orang mukmin adalah bersaudaara, karena itu 
damaikanlah dua orang saudaramu dan takutlah kepada Allah mudahmudahan kamu mendapat rahmat." Hal ini membuktikan bahwa sistem pendidikan yang Allah Swt. ajarkan melalui Rasulullah Saw. sangat efektif dalam membangun masyarakat yang plural dalam mewujudkan masyarakat madani.

Artinya :Dia-lah yang mengutus kepada kaum yang buta huruf, seorang Rasul di antara mereka, yang membacakan ayat-ayat-Nya kepada mereka Kitab dan Hikmah (As Sunnah). Dan sesungguhnya mereka sebelumnya benar-benar dalam kesesatan yang nyata (QS. Al-Jumu'ah: 2)

Kesuksesan pendidikan Rasulullah di atas, patut menjadi langkah dalam perbaikan sistem pendidikan. Apalagi peran sistem pendidikan yang telah ada sekarang, yaitu berdasarkan Undang-undang No. 2 tahun 1989 tentang sistem pendidikan nasional, dirasakan kurang berhasil dalam membentuk manusia seutuhnya (mempunyai kemampuan Iptek dan Imtaq). Karena kualitas sumber daya manusia yang dihasilkan cenderung bersifat sekuler (akibat adanya dikotomi ilmu pengetahuan umum dan agama), materialistis serta individualistis (A. Syafi'i Ma'arif, 1991: 18) akibatnya, individu-induvidu yang terbentuk cenderung memaksakan kehendak (tidak menghormati pluralisme) serta jauh dari nilai-niliai keislaman.

\section{Pendidikan Islam}

\section{Pengertian Pendidikan Islam}

Pendidikan pada dasarnya bertujuan untuk mengembangkan kepribadian seseorang, sehingga ia menjadi manusia yang cerdas dan mampu memecahkan berbagai permasalahan hidup yang dihadapinya.

Menurut Teori Psiko Klasik (Departemen Agama RI, 1997: 128), pendidikan adalah suatu proses dari dalam (inner development). Sedangkan menurut Tohari Mustana (1999: 82) pendidikan dapat diartikan sebagai upaya untuk mengembangkan kepribadian manusia baik dari segi 
psikologi maupun dari segi psikopisik sesuai dengan hakekatnya. Agar menjadi insan kamil (manusia yang sempurna) dalam rangka mencapai tujuan akhir kehidupannya, yaitu kebahagiaan dunia dan akhirat.

Kehidupan seperti ini hanya dapat dicapai dengan melaksanakan ajaran Islam. Karena Islam merupakan agama yang bersifat universal, yang bersumber dari Allah Swt. Kemudian diajarkan kepada Nabi Muhammad Saw. melalui perantaraan Malaikat Jibril As. selanjutnya disampaikan kepada seluruh ummat manusia. Caranya dengan memahami Islam secara baik dan benar, yaitu melalui pendidikan islam.

Menurut Departemen Agama RI (1997: 12) pendidikan Islam adalah suatu proses penyampaian informasi untuk diserap oleh masingmasing pribadi. Sehingga informasi tersebut menjiwai cara berpikir, bersikap, dan bertindak baik untuk diri sendiri maupun terhadap Allah Swt. manusia dan lingkungan serta hubungannya dengan makhluk lain di alam semesta. Dalam kedudukannya sebagai hamba Allah, khalifah di muka bumi, ataupun sebagai ulama penerus para nabi.

Dari pengertian di atas, dapat disimpulkan bahwa pendidikan Islam adalah suatu proses untuk membentuk pribadi atau masyarakat yang Islami.

\section{Tujuan Pendidikan Islam}

Menurut Depag (1997: 143) tujuan pendidikan Islam adalah untuk menciptakan manusia yang berakhlak Islam, beriman, bertaqwa, dan meyakininya sebagai suatu kebenaran serta berusaha dan mampu membuktikan kebenaran tersebut melalui akal, perasaan, dalam seluruh perbuatan dan tingkah lakunya sehari-hari.

Pendidikan Islam tidak hanya mengajarkan atau mentranformasikan ilmu dan keterampilan serta kepekaan rasa atau agama. Tetapi seyogyanya memberi perlengkapan kepada anak didik untuk mampu memecahkan persoalan-persoalan yang sudah nampak sekarang maupun yang baru nampak jelas pada masa yang akan datang. 
Mampu memecahkan persoalan yang dipandang sebagai kewajiban sendiri baik sebagai profesional yang terikat pada kode etik profesinya atau kerena adanya komitmen batin antara dirinya dengan Allah maupun sebagai kewajiban kemanusiaan yang secara sadar dan ikhlas memandang usaha tersebut sebagai langkah yang berguna bagi lingkungannnya. Dengan kata lain, pendidikan Islam harus berorientasi ke masa yang akan datang karena sesungguhnya anak didik masa kini adalah generasi penerus pada masa yang akan datang.

\section{Fungsi Pendidikan Islam}

Pendidikan Islam memiliki berbagai macam fungsi diantaranya adalah:

a. Ibadah

Setiap Muslim dituntut untuk selalu menyembah kepada Sang Khalik (Allah Swt), sebagaimana firman-Nya,

Artinya :"Hanya Engkaulah yang kami sembah dan hanya kepada Engkaulah kami mohon pertolongan" (QS. Al-Fatihah: 5).

Esensi ibadah merupakan inti dari seluruh aktifitas kehidupan manusia dan jin (QS. Adz-Dzariyat: 56). Oleh karena itu, agar aplikasi ubudiyah baik kepada manusia maupun kepada Allah Swt. dapat dilaksanakan sesuai dengan aturan-aturan ilahiyah yang telah ditetapkan, maka setiap pribadi muslim dituntut untuk mengetahui, memahami dan melaksanakan proses penghambaan secara komitmen dan benar, serta diperlukan adanya proses pendidikan sejak lahir hingga wafat agar mencapai tingkat ketaqwaan yang tinggi di sisi Allah Swt.

Allah Swt menyerukan kepada manusia tentang urgensi pendidikan dalam Al-Qur'an:

Tidak sepatutnya bagi orang-orang mukmin itu pergi semuanya (ke medan perang). Mengapa tidak pergi dari tiap-tiap golongan diantara mereka beberapa orang untuk memperdalam pengetahuan mereka tentang agama dan memberi peringatan kepada kaumnya apabila mereka 
telah kembali kepadanya, supaya mereka itu dapat menjaga dirinya (QS. At-Taubah: 122).

Dari pengetahuan yang mereka miliki inilah dijadikan sebagai bekal untuk proses pendekatan diri pada Allah Swt. agar termasuk ke dalam golongan orang-orang yang memperoleh derajat yang tinggi disisi Allah Swt.

b. Kewajiban Menjalankan Perintah Allah (Pewarisan Nilai-Nilai Islam)

Nabi Muhammad Saw. mewajibkan kepada seluruh ummat Islam baik laki-laki maupun perempuan untuk mencari ilmu pengetahuan. Karena dengan ketinggian derajat pengetahuan seluruh muslim dapat menjalankan perintah Allah Swt. demi mencapai keridhaan-Nya. Allah Swt. berfirman:

Artinya: "Katakanlah: Sesungguhnya shalatku, ibadatku, hidupku dan matiku hanyalah untuk Allah, Tuhan semesta alam. Tiada sekutu bagiNya; dan demikian itulah yang diperintahkan kepadaku dan aku adalah orang yang pertama-tama menyerahkan diri (kepada Allah)" (QS. AlAn'am: 162-163).

Proses ketaatan kepada Allah Swt, merupakan ciri khas pribadi Muslim yang kokoh (QS. Al-Luqman: 22, QS. An-Nisa': 125), yaitu orangorang yang menjalankan agama dengan konsekwen dan penuh mengharap rabbnya (QS. Al-Kahfi: 110). Inilah orang-orang yang mendapat gelar Mukhlisun oleh Allah Swt (QS. Shaad: 83). Dan mereka adalah orang-orang yang mendapat jaminan pahala yang besar dari rabbnya (Surga), sebagaimana firman-Nya:

Artinya: "Tidak ada kebaikan pada kebanyakan bisikan-bisikan mereka, kecuali bisikan-bisikan dari orang yang menyuruh (manusia) memberi sedekah, atau berbuat ma'ruf, atau mengadakan perdamaian di antara manusia. Dan barangsiapa yang berbuat demikian karena mencari keridhaan Allah, maka kelak kelak Kami memberi kepadanya pahala yang besar" (QS. An-Nisa': 114). 
c. Kesejahteraan Dunia dan Akhirat

Setiap manusia bertujuan untuk memperoleh kebahagiaan di dunia dan di akhirat (QS. Al-Baqarah: 201). Untuk memperoleh orientasi hidupnya, dibutuhkan adanya unsur yang menunjang, di antaranya adalah ilmu pengetahuan. Rasulullah Saw. Bersabda:

Barangsiapa yang mengharapkan kebahagiaan hidup di dunia, maka hendaklah ia menuntut ilmu pengetahuan. Dan barangsiapa ingin hidup bahagia di akhirat, hendaklah ia menuntut ilmu pengetahuan. Dan barangsiapa yang menghendaki keduanya, hendaklah ia menuntut ilmu pengetahuan juga (HR. Ibnu Sakir).

Tingkat kesejahteraan seseorang baik di dunia atau di akhirat, sangat tergantung pada usaha yang diperbuatnya (QS. An-Najm: 39), semakin besar pengorbanan yang ia keluarkan, maka semakin tinggi pula kesejahteraan yang ia peroleh. Rasulullah Saw. bersabda, "Ya Aisyah, ganjaran yang kamu peroleh sangat tergantung pada kepayahan yang kamu terima" (HR. Bukhari). Dalam Al-Qur'an, Allah Swt. menekankan bahwa setiap kedudukan dari masing-masing individu sangat tergantung pada amalan yang telah ia laksanakan. Perbuatan buruk akan memperoleh balasan setimpal dengan kekejiannya dan amal yang saleh akan memperoleh ganjaran sesuai dengan amal yang telah dikerjakannya.

Allah Swt berfirman:

Artinya: Pada hari itu manusia ke luar dari kuburannya dalam keadaan yang bermacam-macam, supaya diperlihatkan kepada mereka (balasan) pekerjaan mereka. Barangsiapa yang mengerjakan kebaikan seberat dzarrah, niscaya dia akan melihat (balasan)nya. Dan barangsiapa yang mengerjakan kejahatan seberat dzarrah, niscaya dia akan melihat (balasan)nya pula(QS. AlZalzalah : 6-8).

Atas dasar inilah, maka Allah Swt. memerintahkan kepada manusia untuk berlomba-lomba dalam kebaikan dan menjauhi berbagai larangan 
yang telah diatur dalam Kitabullah. Kemudian biarkanlah Allah Swt. dan Rasul-Nya untuk menilai amalan yang telah ia kerjakan.

\section{d. Meninggikan Derajat}

Ilmu pengetahuan merupakan kebutuhan pokok bagi peningkatan intelektual pada diri setiap manusia. Karena hanya dengan inilah, seseorang dapat memberikan kontribusi yang positif bagi pembangunan yang dapat dirasakan oleh lingkungan sekitarnya. Jadi, wajar jika pengembangan ilmu pengetahuan mempunyai korelasi yang kuat dengan kedudukan seseorang di masyarakat. Semakin besar investasi sumber daya manusia yang ia tanamkan, semakin besar pula jasa yang diberikan kepada masyarakat. Manfaatnya adalah tingginya penghormatan masyarakat yang diberikan kepadanya. Hal ini sesuai dengan sunnatullah sebagaimana firman-Nya dalam Al-Qur'an:

Artinya: Dan apabila dikatakan: berdirilah kamu, maka berdirilah, niscaya Allah akan meninggikan orang-orang yang beriman diantaramu dan orang-orang yang diberi ilmu pengetahuan beberapa derajat. Dan Allah maha mengetahui apa yang kamu kerjakan (QS. Al Mujadillah: 11).

\section{Lembaga-lembaga Pendidikan}

Di Indonesia setidaknya ada tiga lembaga pendidikan dilihat dari sisi materi Islam, yaitu sebagai berikut:

\section{Sekolah Umum}

Yaitu, sekolah yang langsung dikelola oleh Kementrian Pendidikan Nasional atau instansi swasta dengan bobot jam pelajaran umum yang sangat banyak dan agama yang sangat sedikit (dua jam pelajaran). Sekolah ini cenderung mengesampingkan pelajaran-pelajaran keagamaan dan hanya mempelajari pengetahuan umum, sehingga anak didik yang dihasilkan cenderung sekuler dan orientasi hidupnya hanyalah materi. 


\section{Pesantren}

Yaitu, lembaga pendidikan yang mayoritas mengajarkan ilmu-ilmu agama dan sedikit ilmu-ilmu umum. Wadah pendidikan ini cenderung melakukan dikotomi ilmu pengetahuan. Akibatnya anak didiknya pun tidak menghasilkan pemikiran yang universal tentang islam. Mereka menjauhi dunia dan terfokus pada kegiatan keakhiratan.

3. Madrasah

Yaitu lembaga pendidikan yang mencoba mengkombinasikan ilmuilmu agama dan keilmiahan agar terbentuk fikrah yang syumul (menyeluruh) terhadap islam. Orientasinya akhirat dengan tetap terpatron kepada dunia merupakan ciri khas dari sifat tawazun (seimbang) dari lembaga pendidikan ini. Dari sinilah terbentuk kader-kader harapan yang dapat membangun masyarakat agar sejahtera dunia dan akherat. "Wahai Tuhan kami berikanlah keselamatan pada kami di dunia dan di akhirat" (Qs.Al-Baqarah: 102).

\section{Perangkat-Perangkat Pendidikan Islam.}

Untuk mendukung keberhasilan suatu pendidikan diperlukan adanya perangkat-perangkat penunjang. Menurut Mastuhu (1996: 25) perangkat-perangkat pendidikan Islam terdiri dari; 1) Aktor atau pelaku, yaitu guru dan murid, 2) Sarana perangkat keras, yaitu masjid dan gedung sekolah, 3) Sarana perangkat lunak, yaitu tujuan pendidikan, kurikulum

\section{Masyarakat Madani}

\section{Pengertian Masyarakat Madani}

Kata madani dalam bahasa inggris sering diterjemahkan sebagai civil society. Sedangkan konsep masyarakat madani dalam bahasa arab mengacu minimal pada dua hal (Abdurrahman, 1999: 13). Pertama, kehidupan Rasulullah dengan pesona keberhasilannya membangun dan 
membina masyarakat yang plural, demokratris, damai, saling menghormati, berdasarkan hukum, hak dan tanggug jawab bersama.

Kedua, dalam konteks sosiologis dunia arab, madani memberi makna kota yang menjanjikan peradaban yang lebih makmur dibandingkan dengan daerah-daerah yang hanya dihiasi dengan panorama gurun pasir yang minus air.

Masyarakat madani memang memiliki kesamaan dengan civil society. Namun tidak identik. Rojaya (1999: 35) membedakan setidaknya dengan dua aspek, yaitu aspek historis dan cakupan maknanya. Dilihat dari segi historis, asal mula madani berpangkal dari perjanjian dengan kesepakatan masyarakat untuk beralih dari kehidupan alamiah yang primitif kearah yang lebih positif. Sedangkan dari tinjauan keislaman didasarkan pada masa lalu yang pasti, yaitu pengalaman umat islam sendiri sepanjang masa keemasannya (Oesman, 1990: 68).

Adapun menurut cakupan maknanya, Didin Hafiduddin di ITB (1999) berpandangan bahwa masyarakat madani mencakup paradigma politik, kemanusiaan dan agama. Jadi, masyarakat madani lebih luas maknanya dibandingkan dengan civil society. Karena civil society hanya berorientasi pada paradigma politik. Jiwa, ketakutan terkena musibah. Kekeringan nilai sepiritual inilah yang Yusuf Qardawi (1996: 35-82) memaparkan kegagalan pembentukan masyarakat madani. Hal ini ditandai dengan munculnya berbagai peradaban yang bersifat negatif di dunia barat, seperti dekadensi moral, keretakan keluarga, kegelisahan berakibat hilangnya nilai-nilai kemanusiaan sehingga terdapat fanatisme suku, tawuran antar pelajar dan meningkatnya angka kriminalitas.

\section{Faktor-faktor yang Mendukung Terwujudnya Masyarakat Madani}

Dalam membangun masyarakat madani diperlukan adanya faktor pendukung, yaitu sebagai berikut: 
a. Pemimpin yang kredibel dan bertanggung jawab (Muhammad, 1999: 171)

Sesuai dengan firman Allah Swt:

Artinya: Sesungguhnya Allah menyuruh kalian menyampaikan amanah kepada yang berhak menerimanya dan apabila menetapkan hukum di antara manusia supaya kalian menetapakan dengan adil. Sesungguhnya Allah memberi pengajaran yang sebaik-baiknya kepada kalian. Sesunguhnya Allah Maha mendengar dan Maha Malihat. Hai orangorang yang beriman taatilah Allah, taatilah rasul, dan ulil amri diantara kalian (QS. An Nisa: 58-59).

Melalui ayat di atas, Allah meyerukan kepada manusia untuk memberikan amanah kepada orang yang memiliki kemampuan dibidangnya masing-masing dengan berpedoman kepada Allah dan RasulNya agar mereka mampu menegakkan norma keadilan kepada seluruh masyarakat tanpa menyia-nyiakan amanah dan bersifat arogan serta memaksakan kehendak. Rasulullah Saw bersabda:

Artinya: Jika amanah disia-siakan maka tunggulah kehancuranny."

Sahabat bertanya: Bagaimanakah menyia-nyiakannya? Beliau menjawab:Jika urusan diserahkan bukan kepada ahlinya maka trunggulah saat kehancurannya (HR.Bukhari).

b. Amar Ma'ruf Nahi Munkar (Madjid, 1999: 161)

Agar dalam sistem pemerintahan itu berjalan dengan efektif maka diperlukan adanya sistim pangawasan baik internal maupun eksternal. Secara internal, sistem pengawasan dapat dilaksanakan oleh pemimpin kepada bawahannya. Sedangkan secara eksternal, pengawasan dapat dilaksanakan melaui pihak oposisi atau lembaga-lembaga negara seperti MPR, DPR, LSM, Mahasiswa, pers, dan lain-lain. Hal ini sesuai dengan firman Allah Swt, 
Artinya: "Dan hendaklah ada di anatara kamu segolongan umat yang menyeru kepada kebajkan, menyuruh kepada yang ma'ruf dan mencegah kepada yang munkar" (QS. Ali Imran: 104).

Adapun metode pengontrolannya yaitu dengan bijaksana sebagaimana firman Allah Swt:

Maka disebabkan rahmat dari Allah-lah kamu berlaku lemah-lembut kepada mereka. Sekiranya kamu bersikap keras dan berhati kasar, tentu mereka akan menjauhkan diri dari sekililingmu. Karena itu maafkanlah mereka, mohonkanlah ampun bagi mereka, dan bermusyawarahlah dengan mereka dalam urusan itu. Kemudian apabila kamu telah membuatkan tekad, maka bertawakkallah kepada Allah.sesungguhnya Allah menyukai orang-orang yang bertawakkal kepadanya (QS. Ali Imran: 159).

Dari pembentukan pribadi-pribadi yang berakhlak mulia inilah, maka mereka dapat mengajak keluarga dan sahabat-sahabat karibnya untuk mempelajari Islam secara kaffah, sebagaimana Rasulullah memberikan dakwah secara sembunyi-sembunyi maupun terang-terangan kepada kerabatnya-kerabatnya. Hal ini dimulai sejak rasulullah menerima wahyu surat Al Muddatsir ayat 1-7 yang berbunyi:

Hai orang yang berkemul (berselimut) bangunlah dan beri peringatan, dan Tuhanmu Agungkanlah, dan pakaianmu bersihkanlah dan perbuatan dosa tinggalkanlah dan janganlah kamu memberi dengan maksud memperoleh balasan yang lebih banyak dan untuk memenuhi perintah Tuhanmu, bersabarlah (QS. Al Muddatsir: 1-7).

Setelah Rasulullah berdakwah kepada kerabat dekatnya (QS. Asy Syura: 214), beliau menyampaikan dakwah secara terang-terngan kepada seluruh masyarakat, baik di Makkah maupun di Madinah untuk meninggalkan perbuatan yang dilarang oleh Allah Swt dan berusaha untuk melaksanakan perintah-perintah-Nya, sebagaimana firman Allah Swt: 
Artinya: Padahal mereka tidak diperintahkan kecuali supaya menyembah kepada Allah dengan memurnikan agama padanya dan menjalankan agama dengan lurus dan supaya mereka mendirika shalat, menunaikan zakat dan demikian itulah agama yang lurus (QS. Bayyinah: 5).

Kemudian setelah dakwah terang-terangan (jahriatul da'wah), Rasululah membangun sebuah masyarakat yang plural, inklusif (keterbukaan), tasamuh (toleransi beragama) yang diimplementasikan dalam sebuah perjanjian Madinah pada tahun keenam Hujriah. Dari sinilah terbentuk sebuah contoh masyarakat yang kokoh dan mengedepankan supremasi hukum atau yang lebih dikenal sebagai masyarakat madani.

Jadi, masayarakat madani akan terbentuk apabila adanya kaderisasi pada setiap pribadi muslim dengan mengikuti pendidikan islam yang kaffah, sehingga ia dapat menyinari (mendakwahi) orang lain kejalan kebenaran. Sebagaimana firman Allah Swt:

Artinya: Hai orang-orang yang beriman peliharalah dirimu, keluargamu dari api neraka, yang kayu bakarnya adalah manusi dan batu, penjaganya malaikat-malaikat yang kasar, keras yang tidak mendurhakai Allah terhadap apa yang doperintahkan-Nya kepada mereka dan selalu mengerjkan apa yang diperintahkan-Nya (QS. Ath Thahrim: 6).

c. Mengedepankan supremasi hukum (Madjid, 1999: 210)

Mengedepankan supremasi hukum berarti bahwa setiap komponen masyarakat dari kelas bawah sampai kelas atas memiliki kedudukan yang sama di depan hukum tanpa adanya diskriminasi dalam hal penetapan hukum. Dalam Al Qur'an Allah menerangkan pada surat Al Baqarah ayat 143, "Begitulah kami jadikan kamu sebagai umat yang pertengahan, supaya kamu menjadi saksi atas perbuatan manusia dan rasul menjadi saksi pula atas perbuatan kamu." 
Inti supremasi hukum tersebut adalah seperti yang tercantum dalam firman Allah Swt:

Artinya: Dan hendaklah kamu memutuskan perkara di antara mereka menurut apa yang diturunkan Allah dan janganlah engkau menuruti hawa nafsu mereka, dan berhati-hatilah kamu terhadap mereka, supaya mereka tidak memalingkam kamu dari sebagian apa telah yang telah diturunkan Allah kepadamu. Jika mereka berpaling (dari apa yang telah diturunkan Allah) maka ketahuilah bahwa Allah menghendaki menimpakan musibah-musibah kepada mereka disebabkan sebagian dosa-dosa mereka. Dan kebanyakan manuasia adalah orang-orang fasik. Apakah hukum jahiliah yang mereka kehendaki, dan (hukum) siapakah yang lebih baik dari pada (hukum) Allah bagi orang-orang yang yakin? (QS. Al Maidah: 45-59).

d. Pendidikan Islam (Hatta, 1999: 210)

Pembangunan masyarakat madani tidak terlepas dari dukungan pendidikan, baik pendidikan formal maupun pendidikan non formal, yang dilaksanakan melalui aturan-aturan ilahiyah yang bersifat holistik dan universal tanpa adanya sebuah dikotomi pemikiran dan sekat-sekat waktu yang membatasi proses pembinaan itu sendiri.Rasullah Saw. Bersabda, "menuntut ilmu itu wajib bagi muslim laki-laki maupun musli perempuan" (HR. Bukhari dan Muslim). Artinya pendidikan tidak mengenal jenis kelamin dan berlaku bagi seluruh umat Islam. Dalam hadis lain Rasulullah bersabda: "Tuntutlah ilmu dari ayunan sampai liang lahat" (HR. Ibnu Abdul Badri).

Hadis di atas, menunjukan bahwa Rasulullah Saw. sangat menganjurkan supaya pembinaan dilakukan sejak dini agar hakekat kehidupan manusia, yaitu untuk beribadah kepada Allah (QS. Az-Zariat: 56) dapat dilaksanakan secara optimal dan hasilnya, yaitu kebahagiaan di dunia dan akhirat dapat dirasakan oleh setiap orang yang mengaktualisasikan esensi Islam islam (QS. Al Baqarah: 201) 
Indikasi keberhasilan pendidikan dapat terlihat dari ketaqwaan kepada Allah Swt. (QS. Al-hujarat: 13). Semakin tinggi ketaqwaan seseorang kepada Allah maka semakin tinggi pula kedudukan ia dengan orang-orang yang berada disekelilingnya. Dan inilah orang-orang yang disebut dalam Al Qur'an sebagai ulama. Allah Swt berfirman,

Artinya" Katakanlah: adakah sama antara orang yang mengetahui dengan orang yang tidak mengetahui, Sesungguhnya orang yang berakallah yang dapat mnenerima pelajaran" (QS. Az-Zumar: 9).

Rasulullah Saw bersabda: "Ulama adalah pewaris para nabi" (HR. Ibnu Najjar). Merekalah yang mengemban amanat ilahiyah denga tetap berpegang teguh pada Al Qur'an dan sunnah walaupun berbagai macam akibat negatif akan diterima, karena misinya hanya satu yaitu berupa pembangunan akhlak manusia. Rasululah bersabda," Aku diutus untuk menyempurnakan akhlak mulia" (HR. Ahmad). Melalui perbaikan ahlak manusia diharapkan terwujud pribadi-pribadi yang mulia hingga ahirnya terbentuk masyarakat Islami dan bercirikan madani.

\section{Kesimpulan}

1. Pembentukan masyarakat madani hanya bisa direalisasikan dengan pelaksanaan pendidikan Islam secara menyeluruh dan berdasarkan pada Al-Qur'an dan Hadits.

2. Faktor-faktor yang mendukung terhadap keberhasilan pendidikan Islam adalah materi pendidikan kurukulum), guru, murid, sarana pendidikan (gedung sekolah dan masjid) dan teknik pengajaran.

3. Adapun tahap-tahap pendidikan Islam yang harus dilalui dalam membangun masyarakat madani adalah pembentukan pribadi muslim yang saleh, dilanjutkan dengan pembinaan keluarga yang islami serta pengkaderan pada lingkungan sekitarnya hingga tercapainya masyarakat yang Islami. 


\section{DAFTAR PUSTAKA}

Abdurrahman, Moeslim. 1999. Islam, Masyarakat Madani dan Demokrasi.

Surakarta: Muhamadiyah University Press.

Al-Qardhawy, Yusuf. 1999. Anatomi Masyarakat Islam. Jawa Timur: Pustaka Kautsar.

Al-Mubarakfury, Safiyur Rahman. 1998. Sirah Nabawiyah. Jakarta: Pustaka Al-Kautsar.

Abdul, Ali. 1995. Dakwah Fardiyah. Gema Insan Press, Jakarta

Daradjat, Zakiah. 1992. Ilmu Pendidikan Islam. Bumi Aksara, Jakarta.

Departemen Agama RI. 1987. Al-Qur'an dan Terjemahannya. Serajaya Santra, Jakarta.

Departemen Agama RI. 1996. Islam Untuk Disiplin IImu Pendidikan. Depag.RI. Press, Jakarta.

Mastuhu. 1994. Dinamika Pendidikan Pesanteren. INIS, Jakarta.

Mustamar,Tohari. 1992. Dasar Dasar Bimbingan konseling Islam. UII Press, Yogyakarta.

Ma'arif, A. Syafi'i dkk. 1991. Pendidikan Islam di Indonesia antara Cita dan Fakta. Yogyakarta: PT. Tiara Wacana Yogya. 